\title{
"After the transition is before the transition" - Experiences of medically induced treatment discontinuation of disease-modifying therapies in people with multiple sclerosis: A qualitative descriptive study.
}

Research article

Keywords:

Posted Date: December 11th, 2020

DOI: https://doi.org/10.21203/rs.2.16027/v2

License: (c) (i) This work is licensed under a Creative Commons Attribution 4.0 International License. Read Full License 


\section{Abstract}

The authors have requested that this preprint be withdrawn due to erroneous posting.

\section{Full Text}

The authors have withdrawn this preprint from Research Square. 